\title{
APPLICATION OF THE CONCEPTS OF QUALITY OF LIFE IN THE HEALTH ASSESSMENT OF POST COVID-19 PATIENTS
}

\author{
Svetlana Gorobievschi ${ }^{1 *}$, ORCID ID: 0000-0003-4600-881X, \\ Tudor Costru², ORCID ID: 0000-0002-9245-1399, \\ Raisa Puia², ORCID ID: 0000-0003-4988-7442, \\ Alina Ungureanu 2, ORCID ID: 0000-0002-0225-0885

\begin{abstract}
${ }^{1}$ Technical University of Moldova, 168 Stefan cel Mare Blvd., MD-2004, Chișinău, Republic of Moldova
2"Nicolae Testemitanu" State University of Medicine and Pharmacy of Moldova, 165 Stefan cel Mare Blvd., MD-2004, Chișinău, Republic of Moldova
\end{abstract} \\ *Corresponding author: Svetlana Gorobievschi, svetlana.gorobievschi@imi.utm.md
}

Received: 17. 07. 2021

Accepted: 20. 08. 2021

\begin{abstract}
The phenomenon of the Covid-19 pandemic has affected the whole globe, the consequences of which are long lasting and difficult to estimate. The Republic of Moldova, being a developing country, could not overcome these serious consequences, caused by the reduction of public health, the reduction of the work capacity of the population, the deplorable condition of the medical system, caused by small investments in health, etc. Human society has been put to hard tests of survival of patients with this virus, the incidence rate of diseases was about $11 \%$. Thanks to the financial aid of the European Union, Romania and other countries, the Republic of Moldova managed to cope with things in the fight against Covid. This article presents the results of the research of the authors, participants of the national project "Assessment of health of post - COVID - 19 patients in the Republic of Moldova", which aimed to develop the Electronic Register of patients with Covid - 19 (March 2020 - June 2021), which will allow monitoring the process of treatment and recovery of the consequences of this disease, by assessing the state of health and quality of life both at admission and at discharge of the respective patients. Based on the concept of quality of life as a socio-economic category and its interconnections with health, the authors proposed the system of medical indicators to assess the health and quality of life of patients affected by covid. In the authors' opinion, a special role in the treatment and treatment of comorbidities belongs to comorbidities, so the authors selected them as separate study subjects to prove their negative impact on the form of the disease and the state of health and quality of life at discharge of patients.
\end{abstract}

Key words: human capital, Covid - 19 pandemic, health status, work capacity, electronic register, objective indicators, subjective indicators, comorbidities, form of the disease, quality of life at discharge. 
Rezumat. Fenomenul pandemiei Covid-19 a afectat globul întreg, consecințele fiind de durată și greu de estimat. Republica Moldova, fiind o țară în curs de dezvoltare, nu putea de una singură să depășească aceste grave urmări provocate de reducerea nivelului de sănătate publică, reducerea capacității de muncă a populației, starea deplorabilă a sistemului medical provocată de investițiile mici în sănătate etc. Societatea umană a fost pusă la grele încercări de supraviețuire a bolnavilor cu acest virus, rata incidenței de înbolnăviri constituind în jur de 11\%. Grație ajutoarelor financiare ale Uniunii Europene, României și altor țări, Republica Moldova a reușit să facă față lucrurilor în lupta cu pandemia. În articolul de față sunt expuse rezultatele cercetării autorilor, participanți la proiectul național „Evaluarea stării de sănătate a pacienților post - COVID - 19 din Republica Moldova”, care au avut scopul de a elabora Registrul electronic de evidență a bolnavilor cu Covid - 19 (martie 2020 - iunie 2021), ce va permite urmărirea procesului de tratare și recuperare a consecințelor acestei boli prin evaluarea stării de sănătate și a calității vieții la internare, cât și la externare a pacienților. Reieșind din conceptul calității vieții ca și categorie socioeconomică și interconexiunile acesteia cu starea de sănătate, autorii au propus sistemul de indicatori medicali de evaluare a stării de sănătate și a calității vieții pacienților afectati de covid. În opinia autorilor, un rol deosebit în parcurgerea și tratarea bolii revin comoborbităților, de aceea autorii le-au selectat pe acestea în calitate de subiect de studiu separat pentru a dovedi impactul lor negativ asupra formei bolii suportate și starea de sănătate și a calitatății vieții la externare a pacienților.

Cuvinte-cheie: capital uman, pandemie de Covid - 19, stare de sănătate, capacitate de muncă, registru electronic, indicatori obiectivi, indicatori subiectivi, comoborbități, forma bolii, calitatea vieții la externare.

\section{Introducere}

Afectată de pandemie și de seceta severă, economia Repblicii Moldova a deminuat în anul 2020, PIB înregistrând o scădere de 7,0 procente. Factorii principali care au determinat acest declin al PIB au fost consumul populației, care a scăzut cu 7 procente, urmat de investiții și de stocuri reduse. Măsurile de carantină au dus la stoparea comerțului și a producției industriale în Republica Moldova, iar seceta severă a afectat agricultura. Nivelul de ocupare a forței de muncă a atins valoarea minimă din ultimii cinci ani. În anul 2021, economia țării a început treptat să-și revină, dar majoritatea indicatorilor de dezvoltare economică pe termen scurt se mențin încă în zona negativă [1].

Starea de sănătate a populației este o componentă a (CV) la nivel mondial și a economiei fiecărei ţări. Speranţa de viaţă, morbiditatea, mortalitatea, aprecierea subiectivă a stării de bine, nivelul cheltuielilor pentru sănătate etc. conturează diagnoze diferenţiate ale sănătăţii, cu relevanţă deosebită în contextul evaluării calității vieții.

Sănătatea este o resursă fundamentală pentru indivizi, comunităţi şi societăţi per ansamblu. Nivelul bun al sănătăţii populaţiei contribuie indispensabil la creşterea economică şi dezvoltarea societăţii umane. Calitatea vieţii desemnează repercusiuni fizice, psihologice şi sociale ale unei patologii asupra vieţii unui pacient $[2,3]$.

Domeniul sănătăţii văzut din perspectiva calităţii vieţii ca inicator complex [1] se referă atât la starea de sănătate, cât şi la serviciile de îngrijire a sănătăţii (acces, utilizare, caracteristici etc.). Speranţa de viaţă a populației, rata de mortalitate, morbiditate, ponderea cheltuielilor în PIB pentru serviciile de îngrijire a sănătăţii reprezintă doar câţiva dintre indicatorii obiectivi folosiţi în cercetarea calităţii vieţii. Fenomenul pandemic provocat în 
R.Moldova a provocat consecințe grele pentru CV a populației din R. Moldova: dimensiunile acestora fiind mult mai grave comparativ cu țările europene și statele megieșe, precum sunt România, Ucraina, Bulgaria [4].

La începutul lunii iunie a anului 2020 o echipă de cercetători din R. Moldova (autorii acestui articol) au inițiat ideea de cercetare științifică cu titlul „Evaluarea stării de sănătate și aprecierea calității vieții pacienților incluși în Registrul electronic COVID-19" [3], cu scopul de a evalua managementul spitalicesc în procesul de tratatre a bolii respective și determinarea consecințelor acestei pandemii asupra sănătății publice și CV la pacienții postcovid. Această idee a fost întărită de Ministerul Sănătății și a căpătat statul al Expresiei de interes cu titlul „Evaluarea stării de sănătate și aprecierea calității vieții pacienților incluși în Registrul electronic COVID-19". Astfel, a fost creat Registrul electronic de evidență al pacienților COVID-19 internați în instituțiile medico-sanitare publice (IMSP) de tip spitalicesc din municipiul Chișinău, pe perioada 2020 - 2021, în scopul evaluării stării de sănătate și aprecierii calității vieții acestora.

Scopul cercetării a constat în determinarea interdependențelor dintre starea de sănătate a pacienților și forma Covd - 19 suportată, care la rândul lor sunt dependenți de comoborbitățile prezente.

\section{Aspecte metodologice de aplicare a categoriei calității vieții în sens medical}

În cercetările CV se consideră că sănătatea poate fi abordată din mai multe perspective. În abordarea CV au fost dezvoltaţi un număr impresionat de indicatori şi indici de calitate a vieţii. Dimensiunea sănătăţii este descrisă prin indicatori subiectivi şi obiectivi.

În domeniul sănătăţii, indicatorii obiectivi ilustrează două dimensiuni: starea de sănătate şi serviciile de îngrijire a sănătăţii. Dimensiunea sănătăţii este măsurată prin intermediul indicatorilor obiectivi: speranţa de viaţă, rata de mortalitate generală, rata de mortalitate pe cauze de deces, rata de morbiditate, incidenţa COVID - ului în populaţie, cheltuielile destinate sănătăţii, alţi indicatori, precum și numărul de cadre medicale, dotarea instituției cu echipament adecvat medical, numărul de instituţii sanitar-medicale, cheltuielile planificate pentru tratamentul pacienților prin prisma cotei PIB. Toate aceste componente caracterizează sistemul medical antrenat în tratamentul pacienților cu COVID-19 [5 - 9].

Pentru evaluarea indicatorilor subiectivi, accentul este pus pe modul în care oamenii îşi evaluiază propria stare de sănătate, constrângerile percepute impuse de starea de sănătate, satisfacţia faţă de propria sănătate, accesul la servicii de sănătate etc. [10 - 13].

Perspectiva esenței CV lărgește aria indicatorilor prin evaluarea indicatorilor obținuți în baza investigațiilor clinice și paraclinice pe perioada spitalizării pacientului. Indicatorii obiectivi au fost obţinuţi la nivel individual din datele softului „Evaluarea stării de sănătate și aprecierea calității vieții pacienților incluși în Registrul electronic COVID-19" (acuzele pacienților cu COVID-19 pe perioada spitalizării și la extenare) și se referă la percepţiile medicilor, evaluările medicale cu privire la starea de sănătate, constrângerile percepute impuse de starea de sănătate și accesul la serviciile de sănătate [4].

\section{Scopul propus al Expresiei de interes a fost realizat prin următoarele:}

- proiectarea și crearea soft-ului „Registrul electronic de evidență al pacienților COVID - 19" pentru USMF "Nicolae Testemițanu";

- elaborarea formularului standardizat pentru evidența paciențiiâlor cu Covid; 
- elaborarea metodologiei de cercetare a calității vieții pacienților cu COVID incluși în registru;

- elaborarea rapoartelor analitice prestabilite în cerectare;

- elaboratea propunerilor pentru îmbunătățirea calității vieții pacienților cu și postCOVID.

Echipa expresiei de interes „Evaluarea stării de sănătate și aprecierea calității vieții pacienților incluși în Registrul electronic COVID - 19” din R. Moldova a considerat oportun a evalua CV unui pacient care a suportat Covid - 19 în baza indicatorilor clinici manifestați de acesta pe parcursul etapelor de tratare: la înmatriculare, perioada de tratament activ și etapa de externare și indicatorii sănătății în aceste perioade. În același timp, echipa a considerat important a efectua evaluarea calității vieții pacienților cu Covid în dinamică, în funcție de forma și gravitatea bolii suportată de pacienții care au formele: asimptomatică, stare medie și stare gravă [3 - 5].

Din experienţa internațională se cunoaște faptul că în determinarea unui anumit nivel al stării de sănătate a populaţiei, stilului de viaţă îi revine o pondere de 40\%, mediului de trai - 20\%, factorilor biologici - 30\%, iar serviciilor de sănătate care intervin direct - doar 10\% [10, 11].

Precum s-a menționat, după puterea de influentă asupra CV, indicatorii sănătății influentează direct și indirect $C V$ a pacientului: indicatori obiectivii (cantitativi) - vin din mediul extern, iar indicatorii subiectivi (calitativi) - vin din mediul intern al IMSP [12 - 17].

Indicatorii subiectivi ai stării de sănătate la internare, expuși de pacienț și confirmați prin diagosticare, simultan devin și indicatorii obiectivi ai stări de sănătate la interanre, care și se introduc în Fișa personală a pacientului, precum sunt [4]:

a) Evaluarea de pacient a propriei stări de sănătate.

b) Satisfacţia acestuia/insatisfacția faţă de starea de sănătate.

c) Autoraportarea unei boli cronice sau a unei dizabilităţi.

d) Percepţia limitărilor în activităţile zilnice datorită stării de sănătate.

e) Imposibilitatea de a munci în ultimul timp din motive de sănătate.

f) Numărul de zile inapte de muncă/şcoală în ultima perioadă.

g) Probleme de sănătate în trecut/prezent (diabet, astm, hipertensiune etc.).

h) Existenţa unui tratament de lungă durată datorită comorbidităților.

i) Motivaţia pentru spitalizarea pacientului cu COVID.

j) Acuzele pacientului/suferinţa fizică (mialgii, fatigabilitate, dispnee etc.) care a afectat activităţile zilnice până la spitalizare.

În baza indicatorilor obiectivi și subiectivi menționați stabilim starea sănătății la internre. Deoarece indicatorii obiectivi au diferită unitate de măsură și nu sunt comensurabili, propunem a evalua starea de sănătate conform indicatorilor subiectivi, care sunt consecința primilor.

Deci, starea de sănătate la internare se stabilește în funcție de gradul și profunzime a acuzelor menționate de pacient. Astfel, după efectuarea testului Covid, la internare se stabilește forma bolii, pacienții fiind grupați în patru grupe după starea sănătății/CV:

- formă ușoară (asimptomatică) - starea sănătății satisfăcătoare;

- formă medie a bolii - stare relativ satisfăcătoare;

- formă relativ grea - satre grea a sănătății;

- formă gravă - stare gravă a sănătății [3]. 
Colectarea și analiza acestor indicatori indirecți a fost necesară pentru determinarea vulnerabilități fiecărui pacient în fucție de vârstă, sex, specialitate, loc de trai și legăturile epidemiologice ale acestuia în dependență de factorii de risc (indicatori obiectivi: dependenți de mediul social și demografic al țării, nivelul de trai și domeniul de activitate). În același timp, aceștia sunt indicatori care influențează indirect starea sănătății sau CV pacientului.

\section{Aplicarea registrului electronic în diagnosticarea stării de sănătate și a calității vieții} la pacienții postcovid

La acest capitol autorii articolului au studiat opiniile existente în lume referitor la locul și rolul comorbidităților în aparitia și evoluția formei bolii de Covid la pacienți. În acest context vom expune opiniile savanților din mai multe țări în această direcție a cercetării.

Prezența bolilor cardiace crește riscul deceselor bolnavilor cu Covid de 12 ori.

Academicianul Academiei Ruse de Științe a Centrului Național de Cercetări Medicale de Cardiologie al Ministerului Sănătății din Rusia Serghei Boytsov scrie în „RIA Novosti”: „Ce se știe despre relație, o astfel de relație fundamentală a patologiilor cardiovasculare și infecția cu coronavirus? Aceste boli nu cresc în mod fiabil riscul de a contracta COVID-19, dar determină un curs mai sever al bolii, cresc riscul de spitalizare în caz de infecție de aproximativ șase ori, crește riscul de deces de 12 ori", a menționat S.Boytsov la o ședință a Consiliului științific al Academiei de Științe din Rusia, „Științele vieții”. Potrivit academicianului, boala de inimă este cea mai frecventă comorbiditate care apare la fiecare al treilea pacient internat cu COVID-19. În același timp, cele mai frecvente complicații ale sistemului cardiovascular în coronavirus sunt tromboza, menționează S. Boytsov [18].

\section{Diabetul zaharat}

Conform cercetărilor efectuate de savanții-medici din Rusia, expuse recent în sursele mass-media de Ministrul rus al Sănătății Mihail Murashko, dintre toate bolile cronice diabetul zaharat este cel mai periculos pentru bolnavii cu COVID - 19. La fel, potrivit Serviciului Național de Sănătate din Marea Britanie, aproape o treime dintre pacienții care au murit din cauza COVID - 19 sufereau de această patologie [19].

În plus, conform portalului Diacheck.ru, astfel de pacienți prezintă un risc crescut de pneumonie severă, insuficiență respiratorie și otrăvire a sângelui. Astfel, în portalul Diacheck.ru se menționează: „Există mai multe motive pentru aceasta. Principala este că diabeticii au un fond imunitar foarte scăzut, astfel încât susceptibilitatea la orice boală infecțioasă este mult mai mare decât a persoanelor fără diabet". Complicarea lucrurilor pacienților cu diabet se datorează secreției corpului cum ar fi urina sau saliva - terenuri de reproducere pentru bacterii. „Și acest lucru, la rândul său, crește riscul apariției oricăror infecții”, a menționat endocrinologul [18].

\section{Bolile sistemului urologic și sistemului cardiac}

La pacienții cu boli renale cronice riscul de deces este de trei ori mai mare. Oamenii de știință de la Pennsylvania State Medical College din SUA au calculat că bolile renale și cardiovasculare se află pe locul al doilea după diabet în ceea ce privește pericolul COVID-19. Studiul a fost publicat în revista "PLOS ONE". Autorii lucrării au analizat datele a peste 65 de mii de pacienți din întreaga lume și au atras atenția asupra a 11 comorbidități care cresc riscul unei evoluții severe a bolii. 


\section{Forma bolii este dependentă de grupul sangvin}

În același timp, cel mai adesea o formă complicată de coronavirus este detectată la persoanele cu al doilea grup de sânge. Oamenii de știință iranieni sunt siguri în acest fapt. Aceeași concluzie a fost făcută de cercetătorii chinezi și americani. Rezultatele tuturor celor trei lucrări sunt publicate pe portalul MedRxiv [20].

Totodată, printre cei care au decedat de coronavirus numărul minim de pacienți a fost printre cei cu prima grupă de sânge. Persoanele cu al treilea sau al patrulea grup de sânge cărora li s-a diagnosticat coronavirusul au prezentat un risc de complicații mai mult decât pacienții cu primul grup de sânge, dar mai puțin decât cei care au avut al doilea grup de sânge.

În luna mai 2020, șeful Agenției Medicale și Biologice Federale din Rusia (FMBA) Veronika Skvortsova a raportat, de asemenea, că printre cei care au fost diagnosticați cu coronavirus, cei mai mulți sunt persoanele cu a doua grupă sanguină. „Un punct interesant, care se află și în literatura străină și care este absolut confirmat în centrele FMBA. Grupul de sânge predominant în rândul celor infectați prezintă pacienți cu grupul doi de sănge, departe de celelalte grupuri de sânge. Pe locul doi se situează pacienții cu al treilea grup de sânge. Cel mai puțini afectați de boală, cu adevărat rar, sunt pacienții cu grupul patru de sânge [19].

\section{Deficitul de vitamine}

Dacă o persoană nu are boli cronice, dar infecția cu coronavirus este încă dificilă, este probabil o chestiune de deficit de vitamine. În special vorbim despre vitaminele D și K.

Grupul de autori au cercetăt situația similară din Republica Moldova, tabelul 1 (Anexa 1 din Registrul Electronic).

Pentru a confirma conceptul că comoborbitățile influențează forma bolii [21 - 29] și starea de sănătate la externare a pacienților cu Covid - 19. În tabelul 1 s-a prezentat informația conform căreia s-au însumat toate comoborbitățile pe IMSP, apoi a fost calculată media comoborbităților per pacient. Astfel, s-a ajuns la concluzia că cel mai inalt nivel al comoborbidtăților per pacient revine următoarelor instituții medicale:

- $\quad$ Printre IMSP cercetate cu pacienți maturi se înregistrează cel mai înalt număr de comoborbităi per pacient la IMSP,,Timofei Moșneaga”, unde, practic, fiecare bolnav de Covid - 19 avea o comoborbiditate. Aici s-a „vindecat” absolut doar un bolnav, iar la restul 66 de pacienți la extrenare starea de sănătate „s-a ameliorat”.

- La IMSP „Sfânta Treime” la extrenare s-au „vindecat” 49 de pacienți sau 22,69\% din total pacienți, iar 70,37\% din pacienti s-au externat cu forma ,ameliorat”.

- La IMSP Spitalul Municipal nr.1 ponderea celor „vindecați” a fost de 61,36\%, iar ponderea celor externați cu forma ,,ameliorat” a fost de 33,3\% din total. În acest caz, se poate trage concluzia că în cadrul Spitalului Municipal nr.1 pacienți au suferit de comoborbități mai puțin grave decât pacienții de la IMSP „Sfânta Treime”.

- La Institutul Mamei și Copilului s-au tratat copii și, de regulă, aceștia nu prea au comoborbidități.

- $\quad$ Analiza datelor biostatistice a dovedit că la IMSP cu numărul de comorbidități per pacient mai mic și numărul pacienților cu forma bolii mai grea sunt mai puțini. Astfel, de exemplu, la IMSP Maternitatea Muncipală, unde această valoare consrtituie 0,25 comoborbidități per bolnav, definitiv s-au „vindecat” 89 de copii, cu ponderea de $35 \%$ din totalul de 250 pacienți. 
Tabelul 1

Starea de sănătate a pacienților post-Covid la externare, 01.02.2020-09.06.2021

\begin{tabular}{|c|c|c|c|c|c|}
\hline \multirow{2}{*}{$\begin{array}{c}\text { Instituțiile } \\
\text { medicale } \\
\text { municipale }\end{array}$} & \multirow[t]{2}{*}{$\begin{array}{l}\text { Forma bolii la } \\
\text { externare }\end{array}$} & \multicolumn{2}{|c|}{$\begin{array}{l}\text { Pacienți la externare și nr. } \\
\text { de comoborbități }\end{array}$} & \multirow{2}{*}{$\begin{array}{c}\text { Total,\% / } \\
\text { comoborbități } \\
\text { per pacient }\end{array}$} & \multirow{2}{*}{$\begin{array}{c}\text { Durata medie a } \\
\text { tratamentului, } \\
\text { zile }\end{array}$} \\
\hline & & pacienți & comoborbității & & \\
\hline \multicolumn{2}{|c|}{ IMSP SCM Boli Contagioase Copii } & 179 & 89 & $100,0 / 0,50$ & 16,34 \\
\hline \multirow{4}{*}{$\begin{array}{l}\text { Stărea de } \\
\text { sănătate la } \\
\text { externare }\end{array}$} & Vindecat & 164 & & 91,62 & \\
\hline & Ameliorat & 13 & & 7,26 & \\
\hline & Agravat & 1 & & 0,56 & \\
\hline & Fără schimbări & 1 & & 0,56 & \\
\hline \multicolumn{2}{|c|}{ IMSP „Arhanghel Mihail” } & 538 & 5 & $100,0 / 0,01$ & 16,68 \\
\hline \multirow{5}{*}{$\begin{array}{l}\text { Stărea de } \\
\text { sănătate la } \\
\text { externare }\end{array}$} & Vindecat & 39 & & 86,89 & \\
\hline & Ameliorat & 468 & & 7,25 & \\
\hline & Agravat & 23 & & 4,28 & \\
\hline & Decedați & 6 & & 1,12 & \\
\hline & Fără schimbări & 2 & & 0,37 & \\
\hline \multicolumn{2}{|c|}{ IMSP Institutul Mamei și Copilului } & 29 & 139 & $100,0 / 4,79$ & 15,50 \\
\hline \multirow{3}{*}{$\begin{array}{l}\text { Stărea de } \\
\text { sănătate la } \\
\text { externare }\end{array}$} & Vindecat & 25 & & 89,66 & \\
\hline & Ameliorat & 2 & & 6,90 & \\
\hline & Fără schimbări & 1 & & 3,45 & \\
\hline \multicolumn{2}{|c|}{ IMSP Institutul de Medicină Urgentă } & 339 & 480 & $100,0 / 1,42$ & 13,61 \\
\hline \multirow{4}{*}{$\begin{array}{l}\text { Stărea de } \\
\text { sănătate la } \\
\text { externare }\end{array}$} & Vindecat & 3 & & 0,88 & \\
\hline & Ameliorat & 260 & & 76,70 & \\
\hline & Decedați & 75 & & 22,12 & \\
\hline & Fără schimbără & 1 & & 0,29 & \\
\hline \multicolumn{2}{|c|}{ IMSP Materinitatea Municipală } & 250 & 63 & $100,0 / 0,25$ & 15,27 \\
\hline \multirow{4}{*}{$\begin{array}{l}\text { Stărea de } \\
\text { sănătate la } \\
\text { externare }\end{array}$} & Vindecat & 89 & & 35,0 & \\
\hline & Ameliorat & 154 & & 61,60 & \\
\hline & Decedați & 6 & & 2,40 & \\
\hline & Fără schimbări & 1 & & 0,40 & \\
\hline \multicolumn{2}{|c|}{ IMSP „Timofei Moșneaga” } & 407 & 137 & $100,0 / 0,37$ & 15,69 \\
\hline \multirow{4}{*}{$\begin{array}{l}\text { Stărea de } \\
\text { sănătate la } \\
\text { externare }\end{array}$} & Vindecat & 1 & & 0,25 & \\
\hline & Ameliorat & 386 & & 94,85 & \\
\hline & Agravat & 19 & & 4,66 & \\
\hline & Fără schimbări & 1 & & 0,25 & \\
\hline \multicolumn{2}{|c|}{ Spitalul Municipal nr. 1} & 411 & 278 & $100,00 / 0,41$ & 17,28 \\
\hline \multirow{4}{*}{$\begin{array}{l}\text { Stărea de } \\
\text { sănătate la } \\
\text { externare }\end{array}$} & Vindecat & 252 & & 61,36 & \\
\hline & Ameliorat & 137 & & 33,33 & \\
\hline & Decedați & 12 & & 2,92 & \\
\hline & Fără schimbări & 10 & & 2,43 & \\
\hline \multicolumn{2}{|c|}{ IMSP „Sfânta Treime” } & 216 & 110 & $100,0 / 0,51$ & 15,50 \\
\hline \multirow{3}{*}{$\begin{array}{l}\text { Stărea de } \\
\text { sănătate la } \\
\text { externare }\end{array}$} & Vindecat & 49 & & 22,69 & \\
\hline & Ameliorat & 152 & & 70,37 & \\
\hline & Decedați & 15 & & 6,94 & \\
\hline \multicolumn{2}{|c|}{ IMSP Boli Contagioase „Toma Ciorbă” } & 10 & 100 & $100,0 / 10,0$ & 15,83 \\
\hline \multirow{3}{*}{$\begin{array}{l}\text { Stărea de } \\
\text { sănătate la } \\
\text { externare }\end{array}$} & Vindecat & 2 & & 20,0 & \\
\hline & Ameliorat & 6 & & 60,0 & \\
\hline & Agravat & 2 & & 20,0 & \\
\hline
\end{tabular}


Continuare Tabelul 1

\begin{tabular}{|l|l|c|c|c|c|}
\hline MSP „Timofei Moșneaga” & $\mathbf{6 9}$ & $\mathbf{6 5}$ & $\mathbf{1 0 0 , 0 / 0 , 9 4}$ & $\mathbf{1 5 , 6 9}$ \\
\hline \multirow{3}{*}{$\begin{array}{l}\text { Stărea de } \\
\text { sănătate la } \\
\text { externare }\end{array}$} & Vindecat & 1 & & 1,4 & \\
\cline { 2 - 6 } & Ameliorat & 66 & & 95,6 & \\
\cline { 2 - 6 } & Decedați & 1 & & 1,4 & \\
\cline { 2 - 6 } & Fără schimbări & 1 & & 1,4 & \\
\hline \multirow{4}{*}{$\begin{array}{l}\text { Stărea de } \\
\text { sănătate la } \\
\text { externare }\end{array}$} & Vindecat & $\mathbf{2 4 4 8}$ & $\mathbf{1 4 6 6}$ & $\mathbf{1 0 0 , 0 / 0 , 6 4}$ & $\mathbf{1 5 , 7 4}$ \\
\cline { 2 - 6 } & Ameliorat & 629 & & $\mathbf{2 5 , 5 7}$ & \\
\cline { 2 - 6 } & Decedați & 1644 & & $\mathbf{6 7 , 1 7}$ & \\
\cline { 2 - 6 } & Agravat & 67 & & 3,97 & \\
\cline { 2 - 6 } & Fără schimbări & 18 & & 2,58 & \\
\hline
\end{tabular}

Sursă: Datele Registrului electronic de evidență a pacienților cu COVID-19. Ch.: USMF, ANCD, 2021

- Forma bolii la extrenare mai mult depinde de comoborbitățile suportate decât de durata medie a tratamentului per pacient. Aceasta o confirmă datele statistice din anexa 1 a Registrului. IMSP care s-au reprofilat la tratarea Covid au utilizat aceleași protocoale medicale europene de tratament și duratele ciclului de tratament sunt cam aceleași, cu unele mici exceptii.

- Micile devieri ale ciclului de tratament apar doar din cauza diferenței structurii pacienților după vârstă, sex și a stării sănătății la internare. De exemplu, dacă la IMSP SCM Boli Contagioase Copii ciclul mediu de tratament a constituit 16,34 zile, la IMSP „Arhanghel Mihail” - 16,68 zile, la IMSP SCR „T. Moșneaga” - 15,59 zile, la IMSP SCR Boli contagioase „T. Ciorbă” - 15,83 zile etc.

\section{Concluzii}

1. Din analiza datelor biostatitce cercetate pe marginea informației prezentate în Registrul electronic elaborat reiese că în peroada mențioată s-au vindecat definitiv pe parcursul tratamentului $25,57 \%$ din total pacienți luați în studiu, care au suportat forma de gravitate medie a bolii și nu sufereau de comoborbități, iar care aveau forma medie a bolii și sufereau de una sau două comoborbitați - au constitut $67,17 \%$ din total bopnavi; care au suportat boala în formă medie-gravă - au fost externați cu starea sănătății ameliorată, fiind supuși pe parcurs unui tratament suplimentar.

2. Cea mai înaltă pondere a pacienților ,vindecați” revine IMSP SCM Boli Contagioase Copii cu ponderea de $91,62 \%$ din total pacienți. Acest fapt poate fi argumentat prin faptul că copiii suportă mai ușor boala. Pe locul doi la acest capitol s-a plasat Institutul Mamei și Copilului cu ponderea celor „vindecați” de 89,66\%. Considerăm că copiii ca pacienți nu pot fi comparați cu pacienții maturi în urma deosebirilor sistemului imunologic al acestora.

3. Cel mai mare număr de bolnavi „decedați” în perioada cercetată (76 pacienți sau 22,12\% din total bolnavi) și celor ,vindecați” complet scade (3 pacienți sau 0,88\% din total) se înregistrează la IMSP SCR Institutul de Medicină Urgentă, care confirmă misiunea IMSP - salvarea pacienților grav bolnavi.

4. Starea sănătății la externare nu depinde de durata tratamentului care se efectuează după aceleași protocoale medicale de către toate IMSP. Mai degrabă, diferența stării de sănătate la extrenare este dependentă de imunitatea individuală a organismului și caracteristicile ficize ale acestuia de a învige boala. 
5. Pacienții „fără schimbări” ale stării de sănătate la externate sunt monitorizați mai departe de medicii de familie sau sunt transporați la alte spitale (în funcție de comoborbitățile avute). Mersul tratamentului acestora nu a fost expus cercetărilor suplimentare, conform obiectivelor stabilite ale expresiei de interes.

6. Concluzia generală: formele de externare a pacienților post-Covid-19 cu comoborbidități expuși tratamențului (conform protocoalelor medicale adaptate la comoborbitățile prezente) influențează direct forma bolii suportate, starea de sănătate la extrenare și CV, care, în final, se apreciază prin rapiditatea relansării capacității de muncă a acestora.

\section{Bibliografie}

1. Alber J., Köhler U. Health and care in an enlarged Europe, Luxembourg, Office for Official Publications of the European Commission, 2004 [Electronic version]. http://www.eurofound.europa.eu/pubdocs/2003/107/en/1/ef03107en.pdf.

2. Gorobievschi S. Aspecte metodologice de evaluare și creștere a calității vieții. Chișinău: Tehnica-INFO, UTM, 2014. 412 p. ISBN 978-9975-63-346-8.

3. „Registrul electronic de evidență al pacienților cu COVID-19”. Expresia de interes la nivel național, Cifrul 20.70086.12/cov [70105] Ch.: USMF, ANCD, 2021.

4. Gorobevschi S. Conceptul calității vieții la interconexiunea cu sănătatea publică. Teze ale conferinţei şt. internaţionale „Implicațiile economice și sociale ale pandemiei Covid-19: analize, prognoze și strategii de atenuare a consecințelor", 23 octombrie 2020/ Comitetul șt.: Stratan Alexandru (preşedinte) [et al.]. Chişinău: INCE, 2020, p.197-199. ISBN 978-9975-3463-3-7.

5. Gorobievschi S., Causan C. Evaluation of health care system quality in the context of medical reform. Journal of Social Sciences, Vol. 2 (3), 2019, UTM, p. 54 - 62. ISSN 2587-3490 e ISSN 2587-3504. Cat. B+

6. The WHOQOL Group // World Health Forum. 1996. V. 17. № 4. p. 354.

7. World Health Organization. Quality of life group. What is it Quality of life? Wid. Hth. Forum. 1996. V.1. P.29.

8. Lozan Oleg, Gramma Rodica. Managementul calității în instituțiile spitalicești / Univ. de Stat de Medicină și Farmacie „Nicolae Testemițanu”, Școala de Management în Sănătatea Publică. - Chișinău: Tipogr. „T-Par”, 2017. - $352 \mathrm{p}$.

9. Novik A.A., Ionova T.I. Guidelines for research on the quality of life in medicine. 2nd edition / ed. acad. Rams Yu.L. Shevchenko. Moscow: ZAO Olma Media Group, 2007. 320 p. [in Russian].

10. Novik A.A., Ionova T.I. Research on the quality of life in medicine. Textbook for universities / ed. Yu.L. Shevchenko. M. GEOTAR-MED. 2004 [in Russian].

11. Shevchenko Yu.L. The concept of research on the quality of life in healthcare in Russia. Bulletin of the International Center for the Study of the Quality of Life, 2003, pp. 3 - 21 [in Russian].

12.Juniper E.F. et al. Determining a minimal change in a disease-specific quality of life questionnaire / J. Clin. Epidemiol. 1994. V. 47. № 1. p. 81 - 87.

13.Juniper E.F. From Genetics to QoL. The Optimal Treatment and Management of Asthma. Hogrete\&Huber Publishers, 1996.

14. Cella D. Measuring quality of life in palliative care. Seminars in Oncology 1995:73-81. 20. Schipper H., Clinch, J.J., Olweny C.L. Quality of life studies: definitions and conceptual issues, In Spilker B Quality of Life and Pharmacoeconomics in Clinical Trials // Lippincott-Raven Publishers: Philadelphia. 1996. p. 11 - 23.

15.Bowling A. Measuring Disease: a review of disease-specific quality of life measurement scales. Buckingham: Open University Press, 1996. 208 p.

16. Aronson N.K. Quality of life assessment in clinical trials: methodologic issues// Control Clin. Trials. 1989. Vol.10. P. 195 - 208.

17. Bowling A. Measuring Health: a review of quality of life measurement scales// 2nd edition. - Open University Press: Philadelphia, 1997. 160 p.

18. https://ria:ru

19. https://www.gazeta.ru/tags/person/nadezhda lebedeva.shtml.

20. http://www.isoqol.org/

21. Hsiao W.C. 1992. Comparing health care systems: What nations can learn from one another. Journal of Health Politics, Policy and Law 17: 613 - 636. 
22. Karnovsky D.A. et al. / Evaluation of Chemotherapeutic Agenta / Ed. by Maclead C.M. Columbia University Press, 1947. p. 67.

23. Elkinton J. R. Medicine and the quality of life // Annals of Internal Medicine. 1966. Vol. 64. p. 711 - 714.

24. Новик А.А., Ионова Т.И., Кайнд П. Концепция исследования качества жизни в медицине. СПб.: Элби, 1999. $140 \mathrm{c}$.

25. George M.R. et al. A comprehensive educational program improves clinical outcome measures in inner-city patients with asthma // Arch. Intern. Med. 1999. V. 159. № 15. p. 1710

26. Mcsweeny A.J., Grant I., Heaton R.K. et al. Life quality of patients with chronic obstructive pulmonary disease. / Arch Intern Med. 1982. p. 473 - 478.

27. Wenger N.K., Mattson M.E., Furberg C.D. et al. Assessment of Quality of Life in Clinical Trials of Cardiovascular Therapies //Am.J. Cardiol. 1984. Vol.54. p. 908 - 913.

28. Donabedian A. Arch. Pathology and Laboratory Medicine. 1990. Vol. 114. p. 1115 - 1118.

29. Guryleva M.E., Zhuravleva M.V., Aleeva G.N. Life quality criteria in medicine and cardiology // Russian medical journal, T.14. №10. 2006. C. 761 -763 [in Russian]. 